\title{
The $\beta$-Globin Dominant Control Region Activates Homologous and Heterologous Promoters in a Tissue-Specific Manner
}

\author{
Greet Blom van Assendelft, Olivia Hanscombe, \\ Frank Grosveld, and David R. Greaves \\ Laboratory of Gene Structure and Expression \\ National Institute for Medical Research \\ The Ridgeway, Mill Hill \\ London NW7 TAA \\ England
}

\begin{abstract}
Summary
We have introduced a human $\beta$-globin minilocus, containing the recently described dominant control region (DCR), the $\beta$-globin or Thy-1 gene, and a thymidine kinase (tk)-neo ${ }^{\beta}$ gene into erythroid and nonerythroid cells. Analysis of the transcription levels of the genes shows that the DCR directs high levels of human $\beta$-globin, Thy-1 and tk-neo expression independent of integration sites in an erythroid-specific manner. The presence of the DNAasel hypersensitive sites at the 5' end of the locus is required for this effect on the homologous and heterologous gene. An analysis of the DCR chromatin In transfected mouse erythroleukemic cells suggests that the formation of the hypersensitive sites in this region precedes $\beta$-globin gene expression.
\end{abstract}

Introduction

The human $\beta$-globin gene is part of a multigene family that is expressed in a tissue- and developmental-specific manner (for review, see Collins and Weissman, 1984). The $\beta$-globin gene is first transcribed in the fetal liver, and becomes fully active when the site of erythropoiesis switches to the (adult stage) bone marrow. The activity of the $\gamma$-globin genes shows a complementary pattern of ex pression; i.e., they are fully active in the fetal liver, but are decreased to very low activity in adult bone marrow. The activation of the human $\beta$-globin gene during erythroid differentiation can be mimicked in transgenic mice and mouse erythroleukemia (MEL) cells (Magram et al., 1985; Wright et al., 1983; Grosveld et al., 1987). It is clear that these processes are regulated by trans-acting factors (Baron and Maniatis, 1986; Wrighton and Grosveld, 1988) that bind to a number of regulatory regions throughout the entire $\beta$-globin gene cluster. In particular, the $\beta$-globin gene and its immediate flanking regions contain a promoter element and two enhancers, which alone, or in combination, give rise to regulated, erythroid-specific expression in transgenic mice (Behringer et al., 1987; Kollias et al., 1987a; Trudel et al., 1987) and MEL cells (Antoniou et al., 1988). Each of these regions is able to bind a number of ubiquitous and erythroid-specific protein factors (Wall et al., 1988; deBoer et al., 1988) but it is, as yet, not clear which of these plays an important role in the tissue- or developmental-specific regulation of the gene. In addition to the immediate flanking regions of the gene, the entire gene cluster is regulated by a region at the $5^{\prime}$ end (and possibly $3^{\prime}$ end) of the gene cluster (Grosveld et al., 1987). Deletion of this region in vivo leads to a classical position effect and the silencing of the $\beta$-globin gene in $\gamma \delta \beta$ thalassemia (van der Ploeg et al., 1980; Kioussis et al., 1983). The deletion is $100 \mathrm{~kb}$ (Taramelli et al., 1986) and contains a $20 \mathrm{~kb}$ region characterized by a set of tissuespecific DNAasel hypersensitive sites (Tuan et al., 1985; Forrester et al., 1987; Grosveld et al., 1987). When this region is added to a human $\beta$-globin gene construct, it results in very high levels of human $\beta$-globin gene expression in transgenic mice, which is related to the copy number, and is independent of the integration site of the transgene (Grosveld et al., 1987). However, it was not clear from these data whether this effect was developmentally specific, nor whether the same effect would be observed if the minilocus were introduced directly into the cells of an erythroid lineage. It was also not clear whether the same would be observed for a heterologous, nonerythroid-specific gene. To answer these questions, we introduced the $\beta$-globin minilocus, including a $\beta$-globin or Thy- 1 gene and a thymidine kinase promoter-driven AGPT hybrid gene (tk-neo) into three types of cells: MEL cells that express $\beta$-globin, K562 cells that express $\gamma$ - but not $\beta$-globin, and mouse $L$ cells that do not express any globin genes, but are permissive for the transcription of transfected globin genes. The results show that the DCR sequence is active and regulates both the $\beta$-globin, Thy- 1 and tk-neo gene in the erythroid cells. No effect is observed in $L$ cells.

\section{Results}

\section{Expression in MEL Cells}

The $\beta$-globin minilocus (Figure 1) was constructed by cloning the upstream and downstream sequences of the $\beta$-globin locus with the $\beta$-globin gene into the cosmid pTCF (Grosveld et al., 1982) from which the Clal site had been removed (Grosveld et al., 1987). This cosmid vector contains the aminoglycoside phosphotransferase (AGPT or neo) gene coupled to the Herpes Simplex Virus thymidine kinase (tk) gene promoter and poly(A) addition sequences (Grosveld et al., 1982). This $45 \mathrm{~kb} \beta$-globin locus recombinant cosmid was linearized with Pvul in the cosmid, leaving the tk-neo at the $5^{\prime}$ end of the molecules and subsequently introduced into C88 MEL cells (Deisseroth and Hendrick, 1978) by electroporation (see Experimental Procedures). Stably transfected populations or individual clones were grown by selection in medium containing the aminoglycoside $\mathrm{G} 418$ and analyzed before and after erythroid differentiation by the addition of DMSO to onehalf of each culture (Antoniou et al., 1988). RNA was prepared from both stages to determine the level of $\beta$-globin expression, and DNA was prepared to determine the structural integrity and copy number of the integrated locus.

Southern blots were carried out with EcoRI digested DNA from eight populations, and Figure $2 \mathrm{~A}$ shows an ex- 


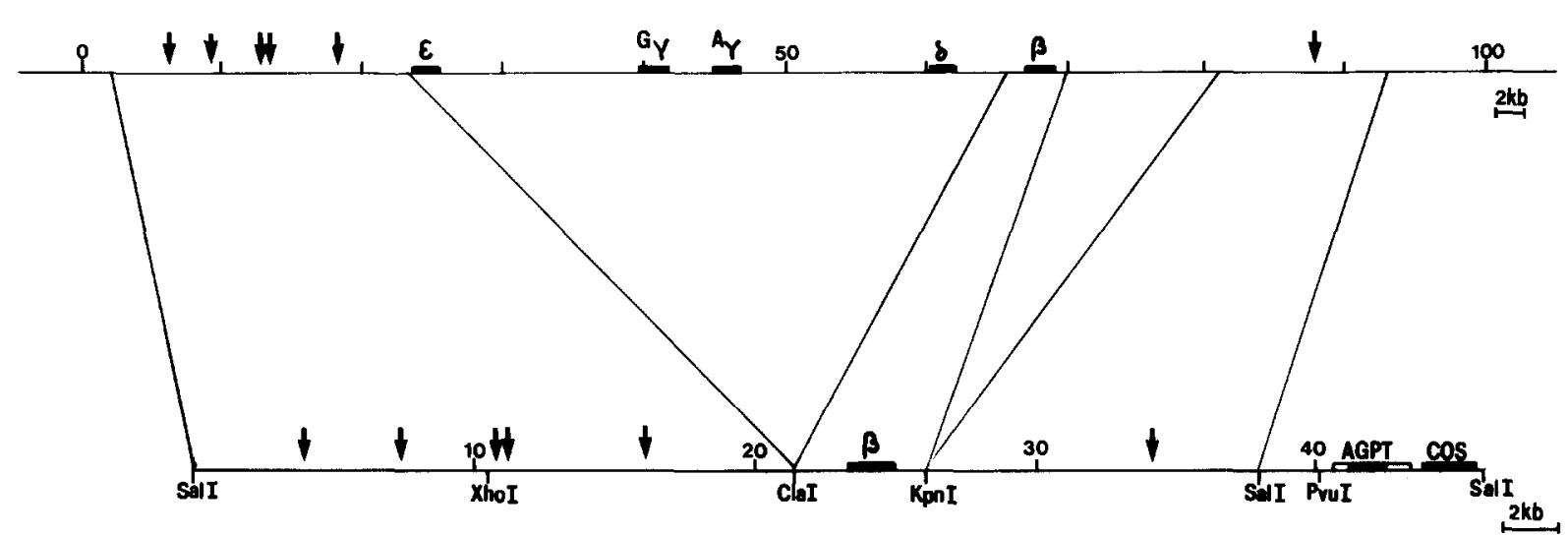

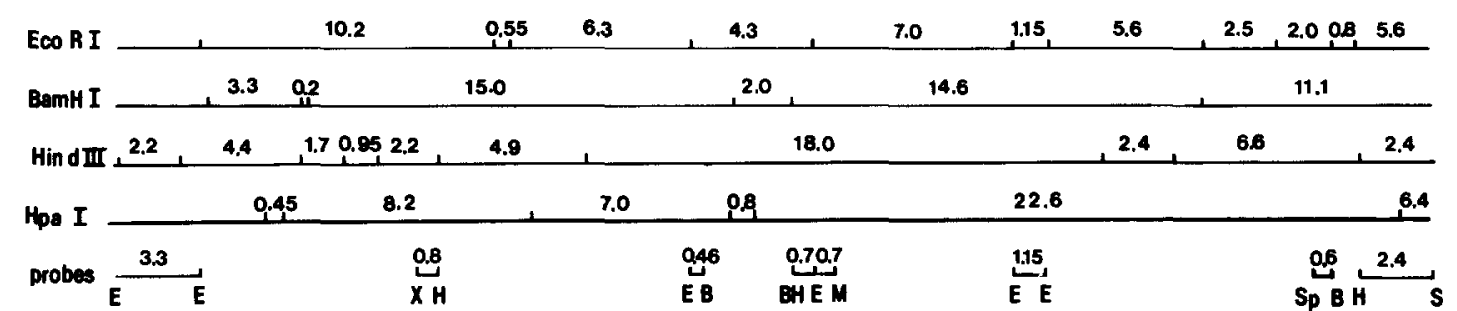

Figure 1. Human $\beta$-Globin Minilocus

The top line shows the human $\beta$-globin locus; the bottom part the constructed human $\beta$-globin minilocus. A number of unique restriction sites is indicated directly on the constructs, while the sizes of the EcoRI, BamHI, HindIII, and Hpal restriction fragments in the minilocus are shown below in kb. On the cosmid pTCF part of the construct, the tk-neo ${ }^{R}$ is indicatcd as the AGPT-box.

At the bottom, the hybridization probes for the $5^{\prime}$-flanking region ( $3.3 \mathrm{~kb} E-\mathrm{E}, 0.6 \mathrm{~kb} X-\mathrm{H}$ and $0.46 \mathrm{~kb} \mathrm{E}-\mathrm{B}$ ), the $\beta-\mathrm{globin}$ gene (0.7 kb B-E and 0.7 $\mathrm{kb} E-\mathrm{M})$, the $3^{\prime}$-flanking region (1.15 kb E-E), and the neo (0.6 kb Sp-B) and cos (2.4 kb H-S) regions of the construct are shown.

$E=E c o R I, X=X h o l, H=$ Hindlll, $B=$ Bglll, $M=M s p l, S p=S p h l, S=$ Sall. Digestion with Pvul results in a cleavage of the amp ${ }^{B}$ region of the cosmid, and produces a linear molecule that carries the tk-neo gene at the $5^{\prime}$ end of the minilocus.

ample of three of the populations using a human $\beta$-globin BamHI-EcoRl second intron probe (Figure 1) and a mouse Thy-1 probe as a control. After densitometer scanning of the bands, an estimate of the copy number of the transfected $\beta$-globin gene can be made (Table 1). This is compared with the expression levels of the $\beta$-globin gene after induction of the MEL cells (Figure $3 A$, left panel, and Table 1), resulting in very high RNA levels per copy of the transfected human $\beta$-globin gene. In most cases, this level is similar to that obtained in transgenic mice (lane 12, Figure 3; Table 1), and is at least 100 -fold higher than the levels obtained without the DCR (Antoniou et al., 1988; data not shown). Additional Southern blot data on the flanking regions of the human $\beta$-globin gene in the populations showed that some of these contained a limited number of end fragments, and thus consisted of a limited number of individual clones (4-5); moreover, some of these carried deletions (e.g., population 3, Figure 2B). We therefore also analyzed nine individual clones, which were derived from the first three populations. A similar analysis was carried out to estimate the copy numbers and expression levels of the transfected gene (Figure 1A, left panel; Figure 3; Table 1). Similar results were obtained, although the overall expression levels in the clones were lower, probably due to the fact that the ratio of mouse $\alpha$ - to mouse $\beta$-globin mRNA has increased, resulting in relatively lower expression of mouse $\beta$-globin mRNA (Table 1). We have at present no explanation why such a selection has taken place.
However, there are a number of exceptions; in this case, clone $k$, which does not express, and clones $t, i$, and $e$, which are exceptionally high. Additional Southern blots were therefore carried out on all of the samples to determine the structure of the entire transfected locus. The analysis (Figure 2B) of a Clal-Sall digest probed with an Xhol-Hindlll fragment (Figure 1) shows that clone $k$ contains the upstream region (Figure $2 B$ ) but not the $\beta$-globin gene itself (Figure 2A). Additional blots show that the tkneo gene is present but not linked to the upstream region in this clone (data not shown). An EcoRI digest of clone i probed with a $3^{\prime} \beta$-globin probe (Eco-Msp, Figure 1) shows that one of the two copies of the $\beta$-globin locus carries a $3^{\prime}$ end deletion. Further blots (EcoRI-Xbal and EcoRI-Pstl; data not shown) show that this deletion includes the enhancer that has been mapped in the $3^{\prime}$ flanking regions of the $\beta$-globin gene (Kollias et al., 1987a; Behringer et al., 1987; Trudel et al., 1987; Antoniou et al., 1988). Analysis of the other overexpressing clones shows that all the copies in clone t contain a $3^{\prime}$ end deletion, leaving the enhancer in place (data not shown), but deleting the hypersensitive site in the $3^{\prime}$ region of the locus (Figure $2 \mathrm{C})$. This suggests that the absence of the 3 ' flanking region may result in an increased expression of the $\beta$-globin gene, although it should be stressed that the other overexpressing clone (e) has no apparent deletions. In fact, it appears to contain the same end fragment as clone f (Figure $2 D$ ), and we have presently no reasonable explanation for 

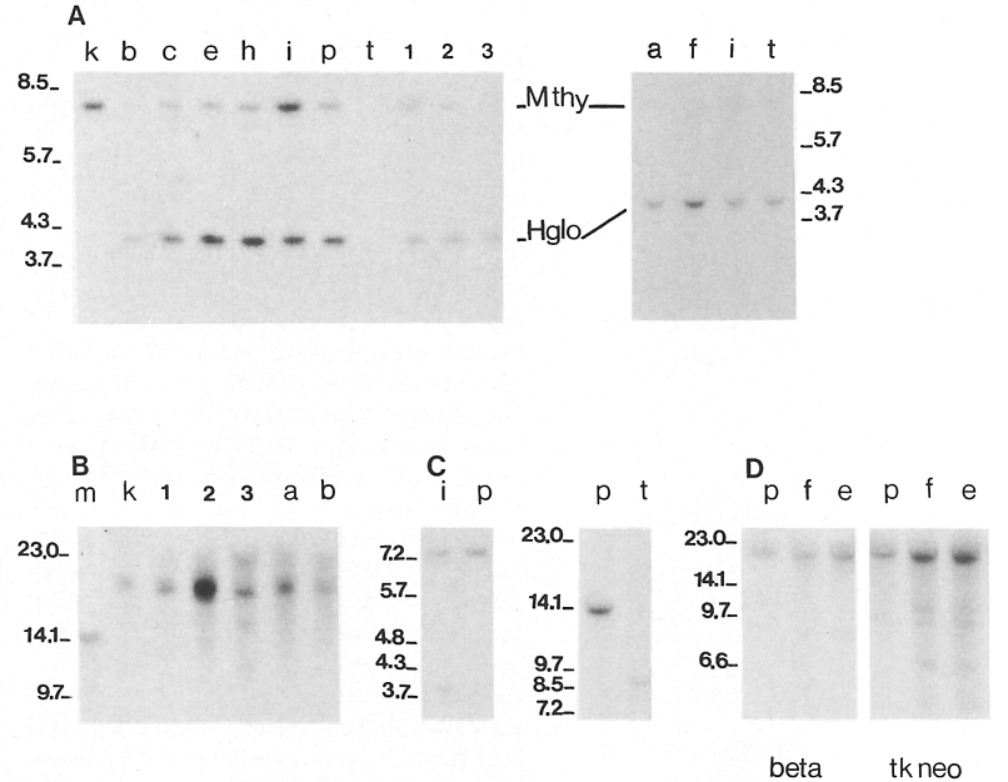

Figure 2. Structural Analysis of the Human $\beta$-Globin MEL Clones and Populations

(A) DNA (approximately $5 \mu \mathrm{g}$ ) was digested with EcoRI, gel-electrophoresed, Southern blotted, and hybridized to the human $\beta$-globin BamHI-ECoRI IVSII probe (see Figure 1) and a mouse Thy-1 probe.

(B) A Sall-Clal double digest was Southern blotted and hybridized to the 5'-flanking probe Xhol-Hindill (Figure 1).

(C) The Southern blot of the EcoRl digest (see A) was washed $(0.2 \mathrm{M} \mathrm{NaOH})$ and reprobed (left two lanes) with the $3^{\prime}$ human $\beta$-globin probe EcoRl-Mspl (Figure 1). Right two lanes: DNA was digested with BamHI, Southern blotted, and hybridized with the human $\beta$-globin BamHI-EcoRI IVSII probe (Figure 1).

(D) An Hpal digest was, after Southern blotting, hybridized to either the human BamHI-EcoRI IVSII probe (Figure 1) or the neo Sphl-Bgll| probe (Figure 1).

On all blots, marker DNA ( $\lambda$-DNA digested with BstEll or HindIII) was run alongside the DNA samples; indicated sizes are in $\mathrm{kb}$. The numbers or letters indicating the MEL populations and clones (respectively) are above the lanes. the expression levels of clone e. Nevertheless, we tested directly whether a deletion of the $3^{\prime}$ region would cause an increase in human $\beta$-globin expression. Three MEL cell populations transfected with a Pvul-Kpnl fragment were generated (hss-5 1, 2, and 3), and their expression levels determined by comparison with the nondeletion population 3 (Figure $3 A$, right panel). All three populations showed an increase of expression per copy of the human $\beta$-globin gene (Figure 3C; Table 1), and we conclude that the deletion causes an increase of expression. It is pres-

\begin{tabular}{|c|c|c|c|c|c|}
\hline $\begin{array}{l}\text { Population } \\
\text { Number }\end{array}$ & $\begin{array}{l}\mathrm{H} \beta-\mathrm{mRNA} / \mathrm{M} \alpha-\mathrm{mRNA} \\
(\mathrm{cpm} \pm 15 \%)\end{array}$ & $\begin{array}{l}\text { Copy Number } \\
( \pm 25 \%)\end{array}$ & $\begin{array}{l}\text { H } \beta / M \alpha \text { RNA per } \\
\text { H } \beta \text { DNA }\end{array}$ & $\begin{array}{l}\text { H } \beta / M \beta \text { RNA per } \\
H \beta \text { DNA }\end{array}$ & $\begin{array}{l}M \alpha / M \beta \\
( \pm 30 \%)\end{array}$ \\
\hline 1 & $2800 / 1370$ & 2.3 & 0.9 & 0.3 & 0.4 \\
\hline 2 & $19400 / 2100$ & 6.7 & 1.4 & 0.5 & 0.5 \\
\hline 3 & $6550 / 990$ & 5.9 & 1.1 & 0.4 & 0.4 \\
\hline 4 & $3090 / 1700$ & 1.8 & 1.0 & 0.5 & 0.5 \\
\hline 5 & $5850 / 1100$ & 4.0 & 1.3 & 0.3 & 0.2 \\
\hline 6 & $3060 / 770$ & 3.1 & 1.3 & 0.3 & 0.2 \\
\hline 7 & $3410 / 1100$ & 2.7 & 1.2 & 0.3 & 0.2 \\
\hline 8 & $860 / 1370$ & 0.5 & 1.2 & 0.4 & 0.3 \\
\hline mouse 12 & $3080 / 1450$ & 2.0 & 0.9 & 0.4 & 0.4 \\
\hline \multicolumn{6}{|l|}{ Clone } \\
\hline a & $450 / 220$ & 5 & 0.4 & 0.1 & 0.3 \\
\hline b & $250 / 160$ & 5 & 0.3 & 0.2 & 0.7 \\
\hline$c$ & $130 / 120$ & 4 & 0.3 & 0.2 & 0.7 \\
\hline e & $3280 / 220$ & 6 & 2.5 & 1.6 & 0.7 \\
\hline$f$ & $380 / 200$ & 7 & 0.3 & 0.2 & 0.9 \\
\hline h & $300 / 180$ & 7 & 0.2 & 0.2 & 0.9 \\
\hline$i$ & $240 / 200$ & 2 & 0.6 & 0.4 & 0.6 \\
\hline$p$ & $320 / 190$ & 5 & 0.3 & 0.2 & 0.8 \\
\hline$t$ & $1880 / 320$ & 3 & 2.0 & 0.9 & 0.5 \\
\hline \multicolumn{6}{|l|}{ Population } \\
\hline hss-5,1 & $3770 / 1360$ & 0.2 & 13.9 & 4.6 & 0.3 \\
\hline hss-5,2 & $9740 / 1650$ & 0.6 & 9.8 & 2.8 & 0.3 \\
\hline hss- 5,3 & $15940 / 1360$ & 1.0 & 11.7 & 3.1 & 0.3 \\
\hline
\end{tabular}

H $\beta$-mANA/M $\alpha$-mRNA represents the average amount of human $\beta$-globin and mouse $\alpha$-globin mRNA in two separate experiments by excising $S 1$ nuclease-protected fragments from the gel and counting in a liquid scintillation counter. The copy number of the human $\beta$-globin DNA per cell is obtained by densitometry of the $\beta$-globin DNA signal on Southern blots and normalization to that obtained for Thy-1. H $\beta /$ Ma per H $\beta$ DNA represents the ratio of human $\beta$ - and mouse $\alpha$-globin DNA (in cpm) divided by the copy number.

$H \beta / M \beta$ RNA per $H \beta$ DNA is the same as the previous column but using mouse $\beta$-globin RNA as the standard. M $\alpha / M \beta$ represents the ratio of the mouse $\alpha$ - to mouse $\beta$-globin mRNA levels. 


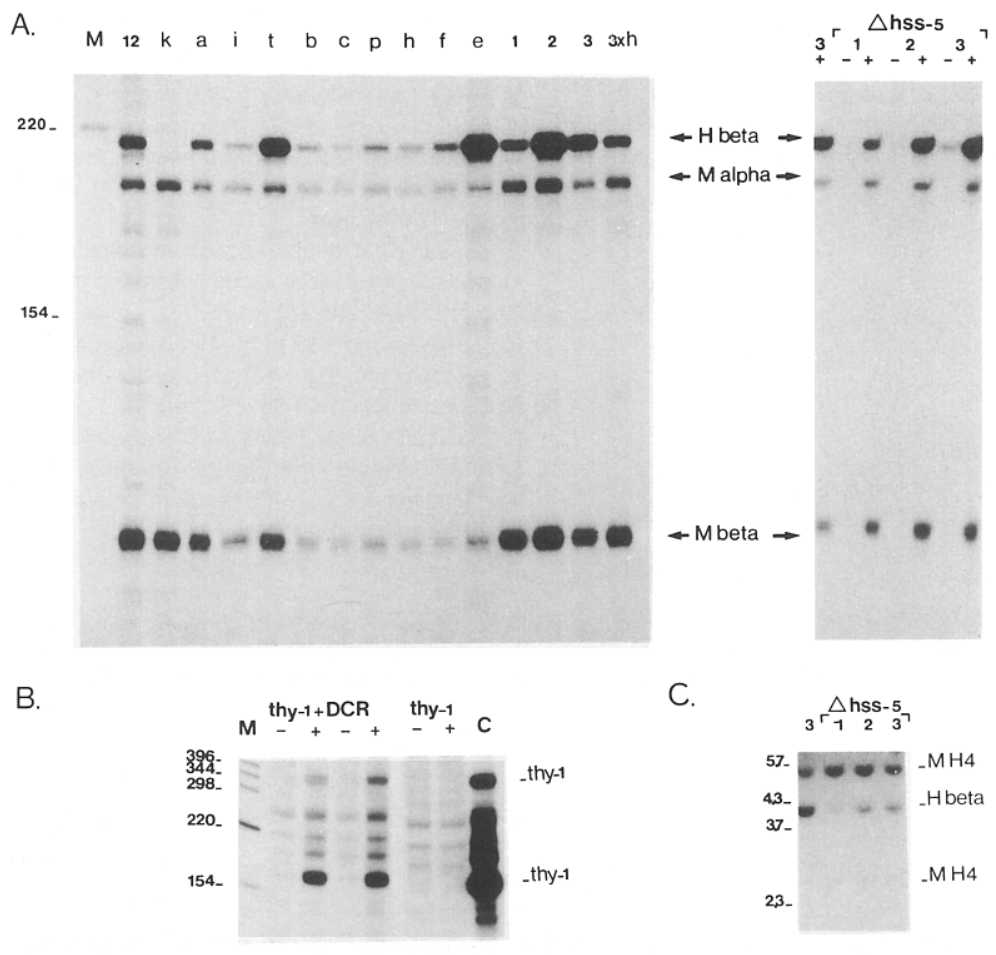

Figure 3. Expression Analysis of the Human $\beta$-Globin and Thy-1 MEL Clones and Populations by Nuclease S1 Mapping

(A) Left: ten micrograms of RNA from induced MEL clones and populations (numbered above the lanes) transfected with the $\beta$-globin construct was analyzed by $\mathbf{S} 1$ nuclease protection (Kollias et al., 1986), using a mixture of three different probes: a $3^{\prime}$ human $\beta$-globin probe (760 bp EcoRI-Mspl fragment, Figure 1) resulting in a 210 nucleotide protected fragment $(H$ beta); a mouse $\alpha$-globin probe (260 bp BamHI second exon probe), resulting in a 170 nucleotide protected fragment ( $M$ alpha) and a mouse Bmaj probe (230 bp HindllI-Ncol second exon probe) to give a 100 nucleotide protected fragment ( $M$ beta).

The positive control is transgenic mouse 12 , made with the $38 \mathrm{~kb}$ Sall fragment of the human $\beta$-globin minilocus (Grosveld et al., 1987). In lane $3 \times \mathrm{h} 30 \mu \mathrm{g}$ of RNA from clone $\mathrm{h}$ was used as a control for excess probe.

Right: S1 nuclease protection analysis on 10 $\mu \mathrm{g}$ of RNA from uninduced $(-)$ and induced $(+)$ MEL populations transfected with the $\beta$-globin minilocus after deletion of the $3^{\prime}$ region. The first lane (labeled 3 ) is the same sample 3 as in the left panel.

(B) S1 nuclease protection analysis (Kollias et al., 1987b) of $20 \mu \mathrm{g}$ of RNA from uninduced (-) and induced $(+)$ MEL cell populations after transfection with the Thy-1 gene alone (Thy-1) or the Thy-1 gene replacing the $\beta$-globin gene in the minilocus cosmid (Figure 1). Positive control $\mathrm{C}$ contains $1 \mu \mathrm{g}$ of brain RNA.

Lane $M$ in $(A)$ and $(B)$ is a marker (pBr322 $\times$ Hinfl) indicated in nucleotides.

(C) Southern blot analyses of the DNA from MEL cell populations transfected with the $\beta$-globin minilocus without the $3^{\prime}$ hypersensitive region (i.e., minus the Kpnl-Pvul fragment in Figure 1).

Five micrograms of DNA was digested with EcoRI, Southern blotted, and hybridized to the mixed human $\beta$-globin IVSII probe (BamHIEcoRI) and the mouse histone $\mathrm{H} 4$ (MH4) probe. The control lane contains EcoRI-digested DNA from $\beta$-globin minilocus MEL population 3.

Marker DNA ( $\lambda$-DNA digested with BstEII) was loaded alongside the DNA samples; marker band sizes are indicated in kb.

ently not clear whether this is caused by a "distance" effect or the absence of an active hypersensitive site 5 region.

Further $S 1$ protection analysis showed that all of the clones have very low levels of human $\beta$-globin expression before induction, with the exception of clone $e$ (not shown) and population hss- 5 no. 3 (Figure $3 A$, right panel). The same expression pattern is observed when the levels of human $\beta$-globin and tk-neo RNA were analyzed on Northern blots after reprobing of the blot for the presence of mouse $\alpha$-globin and histone $\mathrm{H} 4$ mRNA as the induction of differentiation and RNA loading controls, respectively (Figure 4). Not surprisingly, the tk-neo gene is expressed at low levels before induction to provide G418 resistance, but it is dramatically increased after the induction of MEL cell differentiation following the pattern of human $\beta$-globin gene expression. The tk-neo is at least $50-100$-fold higher than that observed in the absence of the flanking regions (clone $k$ and Antoniou et al., 1988), and shows that these regions exert a dramatic effect on this heterologous promoter.

To test whether the induction of the tk-neo gene requires the presence of the human $\beta$-globin gene and its enhancers, we replaced the globin gene with a human-murine hybrid Thy-1 gene (Kollias et al., 1987b). The resulting transfected populations were compared with populations containing the Thy-1 and tk-neo genes without the DCR.
Northern blot (Figure 4, right panel) and S1 nuclease protection analysis (Figure $3 \mathrm{~B}$ ) show that the tk-neo gene is still induced at high levels without the $\beta$-globin gene and that the transfected Thy- 1 gene is also induced to express. Very low levels (at least 50-fold lower for tk-neo) or undetectable levels (for Thy-1) are observed without the DCR, demonstrating that both inductions are completely dependent on the presence of this region.

We subsequently tested whether the DNAasel hypersensitive sites in the $5^{\prime}$-flanking region had been reformed after transfection into MEL cells (Figure 5). Surprisingly, all of the hypersensitive sites are already present before the induction of the MEL cells, including the hypersensitive site in the $3^{\prime}$ flanking region, which was not reformed in transgenic mice (Grosveld et al., 1987). It should be pointed out, however, that this site does not increase in intensity on the blots with increasing DNAasel digestion, and therefore behaves differently to the others. In addition to the human globin-specific hypersensitive sites, a very strong hypersensitive site is observed in the tk-neo promoter region.

\section{Expression in K562 and L Cells}

We then asked the question whether the minilocus construct would be active in erythroid cells representing a different stage of development or in a non-erythroid cell 


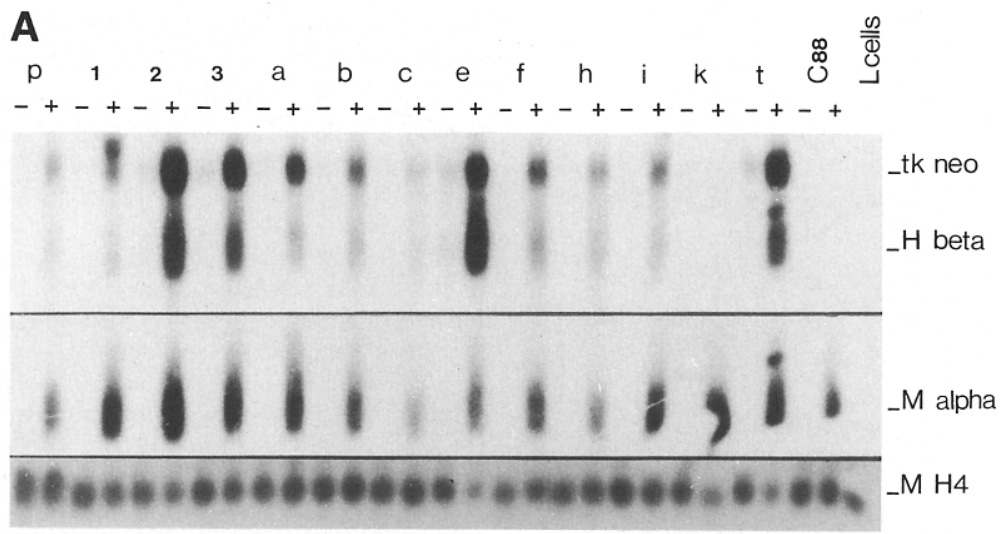

B

$$
\text { C } \Gamma^{\text {thy }-1} \text { thy }-1+\text { DCR }^{\text {th }}
$$

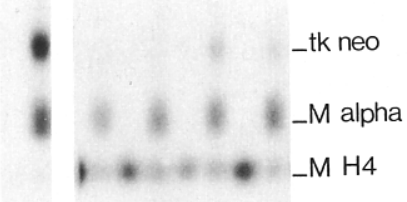

Figure 4. Expression Analysis of the Human $\beta$-Globin and Thy-1 MEL Clones and Populations by Northern Blotting

Fifteen micrograms of RNA from uninduced $(-)$ as well as induced $(+)$ clones and populations was Northern blotted after gel electrophoresis, and hybridized to either a mixture of the Sphl-Bgill neo probe (tk-neo, Figure 1), together with the EcoRl-Mspl human B-globin probe (H beta, Figure 2), or the mouse $\alpha$ BamHI second exon probe ( $\mathrm{M}$ alpha) or mouse $\mathrm{H} 4$ probe $\left(\mathrm{MH}_{4}\right)$ in a separate rehybridization. $\mathrm{RNA}$ from untransfected $\mathrm{MEL}-\mathrm{C} 88$ and $L$ cells was used as a negative control.

line. The human cell line K562 (Lozzio and Lozzio, 1975), which expresses the human $\gamma$-, but not the $\beta$-globin gene, was chosen for the first purpose, since it had been shown previously that transfected $\gamma$-, but not $\beta$-globin genes (without flanking regions) can be expressed in these cells (Kioussis et al., 1985; Antoniou et al., 1987; Rutherford and Nienhuis, 1987). Mouse $L$ cells were chosen as a nonerythroid cell, since it has been shown that this cell is capable of expressing transfected $\beta$-globin genes (Dierks et al., 1981; Busslinger et al., 1983; Murray and Grosveld, 1987).

Southern blots using mouse Thy-1, human $\beta$-globin, and tk-neo as probes were used again to establish the copy number and the integrity of the transfected locus. Figure 6 shows that each of the $L$ cell populations contains a fairly low number of $\beta$-globin and tk-neo genes $(3,2,2$, and 5 , respectively), while the $\mathrm{K} 562$ cell populations contain one high and two low copy numbers $(10,2$, and 1 , respectively). Surprisingly, the transfected K562 cells express the human $\beta$-globin gene, and the copy number of the transfected gene is reflected in the expression levels of the $\beta$-globin gene by $S 1$ nuclease protection analysis (Figure 7, middle panel) and Northern blots (Figure 7, lower panel). Comparison of the levels of $\gamma$ - and $\beta$-globin RNA shows that the level of expression per $\beta$-globin gene is approximately 5 - to 10 -fold lower than that of the $\gamma$-globin

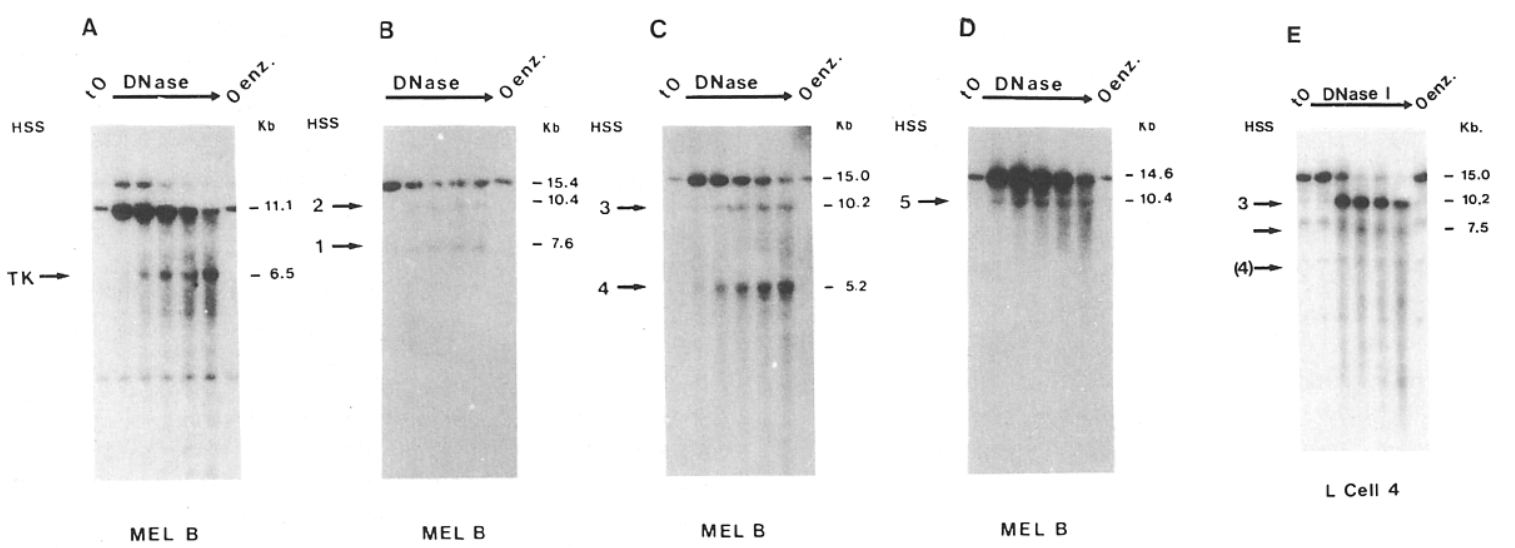

Figure 5. Analysis of the DCR DNAase Hypersensitive Sites

(A)-(D) Nuclei were prepared from approximately $10^{8}$ uninduced cells of MEL clone B, and digested with $10 \mu \mathrm{g}$ of DNAasel per ml for increasing times at $37^{\circ} \mathrm{C}$. DNA was prepared and digested to completion with restriction endonucleases BamHI (A), (C), (D) or Bglll (B). After electrophoresis and transfer to nitrocellulose, DNA samples were probed with a $3.3 \mathrm{~kb}$ EcoRl probe (A) and (B), a $0.46 \mathrm{~kb}$ EcoRI-BamHI fragment (C), or a 1.15 $\mathrm{kb}$ EcoRI fragment (D). Samples labeled tO are DNA prepared from nuclei before the addition of DNAasel; samples labeled Oenz. are from nuclei incubated in the absence of DNAasel for $20 \mathrm{~min}$ at $37^{\circ} \mathrm{C}$.

(E) Nuclei were prepared from approximately $2 \times 10^{7} \mathrm{~L}$ cells of population 4, and digested with $10 \mu \mathrm{g}$ of DNAasel per ml for increasing times at $37^{\circ} \mathrm{C}$. DNA was prepared and digested with BamHI. After electrophoresis and transfer to nitrocellulose, DNA samples were hybridized as (C). Positions where erythroid-specific DNAasel sub-bands would be expected are indicated by arrows 3 and (4). One of the myeloid-specific sub-bands at $7.5 \mathrm{~kb}$ is indicated with a plain arrow. The blots to detect sub-bands corresponding to sites 1 and 2 used a Bglll digest and probe as in (b). No sub-bands were detected (data not shown). 


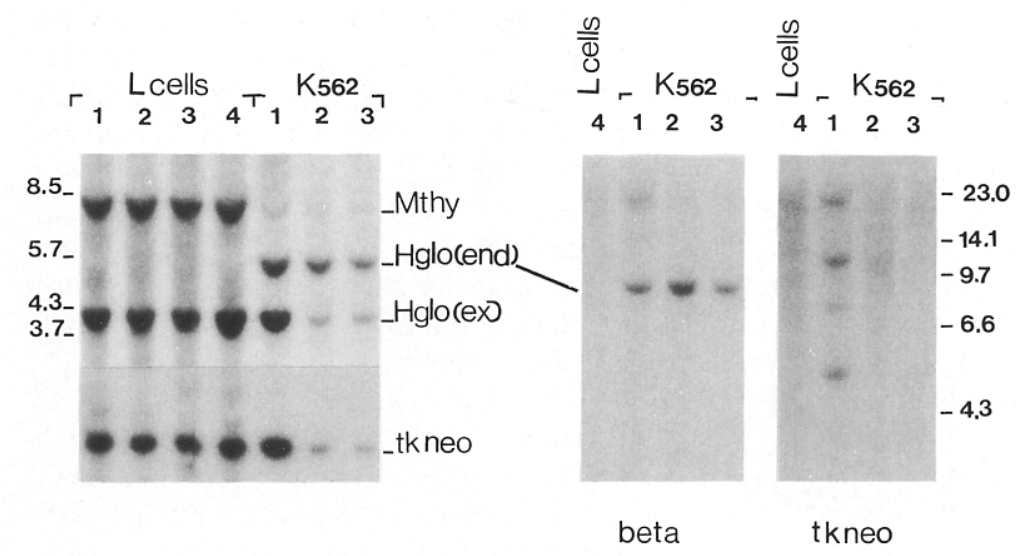

Figure 6. Structural Analysis of the Human $\beta$-Globin $K 562$ and $L$ Cell Populations

Left: DNA of the different populations was digested with EcoRI, gel electrophoresed, and Southern blotted. The blot was hybridized to the human $\beta$-globin BamHI-EcoRI IVSII probe ( $H$ glo, Figure 1), a mouse Thy-1 probe ( $M$ thy), and the Sphl-Bgill neo probe (tk-neo, Figure 1). In the K562 populations, the endogenous human $\beta$-globin genes ( 3 copies) show up as a $5.2 \mathrm{~kb}$ EcoRl fragment ( $\mathrm{H}$ glo [end]).

Right: Hpal digests of the DNA samples were run out on an agarose gel and Southern blotted. The blot was hybridized either with the human B-globin BamHI-EcoRI IVSII probe (Figure 1), or the SphI-Bglll neo probe (Figure 1).

The different $L$ cell and K562 populations are indicated by their number above the lanes. gene. Analysis of the $\beta$-globin expression in the $L$ cell populations shows that the gene is expressed in all cases (Figure 7, L cells, lanes 1-4) at levels that are comparable to those obtained without the flanking regions (lane 5). Analysis of the tk-neo expression levels shows one curious anomaly (Figure 7, lower panel). In the K562 populations the tk-neo mRNA levels are high, but in the case of population 1, it does not follow the expression levels of the $\beta$-globin gene. Southern blot analyses (Figure 6 and data not shown) indicate that the majority of the tk-neo genes are intact in this population. Apart from the suggestion that some limiting factor would prevent higher expression levels and that the expression levels of tk-neo would already be maximum in the lower copy number populations, we have at present no explanation for this result. Analyses of the populations for the presence of the DNAasel hypersensitive sites show that the sites return in the K562 cells as expected (data not shown), but that they cannot be detected in the $L$ cell population, with the exception of hypersensitive site 3 (Figure 5E and data not shown). This site is reformed very efficiently in these non-erythroid cells together with two other sites (at $7.5 \mathrm{~kb}$ and $5.5 \mathrm{~kb}$ in Figure $5 \mathrm{E})$, which were originally mapped by Forrester et al. (1987) to be present in the chromatin of non-erythroid hematopoietic cells.

\section{Discussion}

\section{Erythroid-Specific Expression}

It is clear from these data that the stable transfection of a $\beta$-globin gene minilocus, including the flanking regions, results in a copy number-dependent and integration position-independent expression of the gene in differentiated MEL cell populations and clones. The expression level per gene copy is at a similar level to that of the endogenous globin genes. The effect of the flanking regions is erythroid-specific, since copy number-dependent expression is also obtained in K562 cells. This effect is not observed in the non-erythroid L cells, where low levels of expression are obtained, similar to those obtained without the flanking regions (Dierks et al., 1981; Busslinger et al., 1983; Murray and Grosveld, 1987). These results are therefore very similar to those obtained in transgenic mice (Gros- veld et al., 1987), and show that the $\beta$-globin locus does not need to undergo a complete developmental differentiation program to be expressed at high levels. Neverthe-

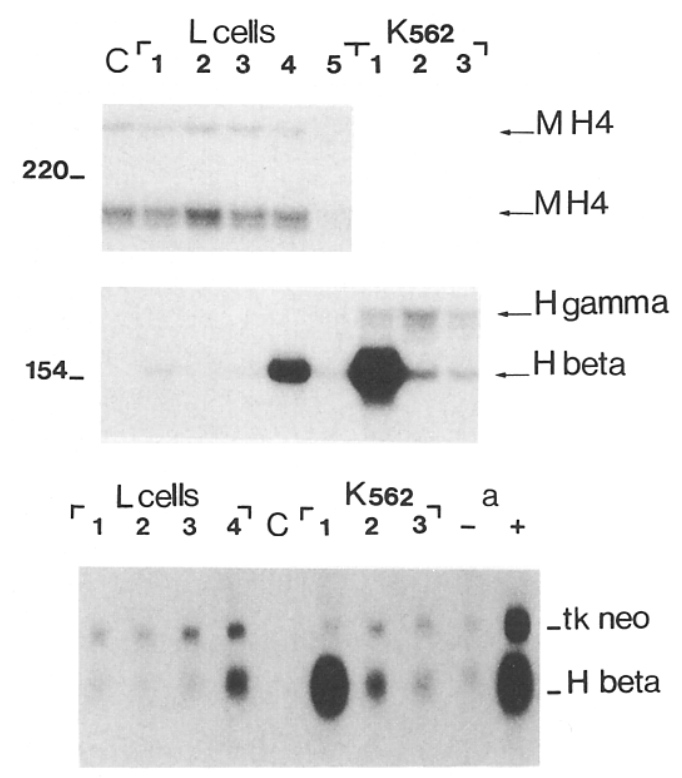

Figure 7. Expression Anatysis of the Human $\beta$-Globin L Cell and K562 Populations

Top: five microgram aliquots of RNA from the $L$ cell and $K 562$ populations were analyzed by $S 1$ nuclease protection (Kollias et al., 1986) using a mixture of a $5^{\prime}$ human $\beta$-globin (Accl) probe (protected fragment: $H$ beta) and a $3^{\prime}$ human $\gamma$-globin probe of 10-fold lower specific activity (protected fragment: $\mathrm{H}$ gamma). Only $0.5 \mu \mathrm{g}$ of $\mathrm{L}$ cell RNA was used for the endogenous histone $\mathrm{H} 4$ control in the $\mathrm{S} 1$ nuclease protection experiments (protected fragments MH4). Untransfected L cell RNA (c) was included as negative control (lane c) and RNA from an L cell population containing just the human $\beta$-globin gene, but not the DCR sequences, was included as positive control (lane 5; Murray and Grosveld, 1987). Labeled pBr322 DNA digested with Hinfl was run alongside the experiments; sizes are indicated in nucleotides.

Bottom: fifteen micrograms of RNA of each population was Northern blotted after gel electrophoresis and probed with the human $\beta$-globin EcoRl-Mspl probe (Figure 1; $\mathrm{H}$ beta) as well as the Sphl-Bgill neo probe (Figure 1; tk-neo). As positive control, RNA from both the uninduced (-) and the induced (+) MEL clone was included.

The different populations are indicated by their number above the lanes. 
less, some differences are apparent. In the cell cultures, a selection is applied (G418) for the expression of the linked tk-neo gene, which will therefore ensure that the transfected DNA is integrated in a transcriptionally active domain. This is reflected in the variations of the low levels of transcription of the tk-neo gene (and the $\beta$-globin gene) before the induction of the MEL cells (Figure 3 ), and implies that the minilocus does not isolate (silence) the gene from the neighboring chromatin. Once the cells have been induced by DMSO, the levels of expression increase by at least 100-fold and become independent of the position of integration. Such effects could not be observed in transgenic mice, because there is no selection for integration into active chromatin, nor does an "uninduced" stage of expression exist in isolation. As a consequence, it is only possible in the cell culture system to detect the presence of the hypersensitive sites before the induction of $\beta$-globin transcription, and their presence at this stage suggests that the erythroid-specific (open) chromatin structure is not coupled $\beta$-globin transcription. Interestingly, hypersensitive site 3 and the myeloid hypersensitive sites (Forrester et al., 1987) also return in the non-erythroid-specific $\mathrm{L}$ cells (Figure 5 ). The formation of this site can therefore be mediated by non-erythroid-specific factors, although these apparently do not exert any transcriptional effect in the (non-erythroid) $L$ cells. The significance of this is presently unclear, but it suggests that the formation of site 3 may be dependent on it being present in "active" chromatin. The latter is assured in these experiments by virtue of the G418 selection after transformation.

The deletion of the $3^{\prime}$ hypersensitive site appears to have a stimulatory effect on the transcription of the $\beta$-globin gene. At present, this could also be explained by a position effect resulting from the large deletion, but it is interesting to note that the expression of the $\gamma$-globin gene in the deletion forms of HPFH, which removes this whole region, is higher than the level observed in patients who carry a deletion of only (parts of) the $\beta$-globin gene (for review, see Poncz et al., 1989).

\section{Expression of the Thy-1 and tk-neo Gene}

The presence of the flanking regions also results in a dramatic stimulation of transcription of the non-erythroid-specific promoter of the HSV thymidine kinase (tk) gene after differentiation of the MEL cells. Interestingly, when an SV40-neo hybrid gene is introduced into the human $\beta$-globin locus on chromosome 11 of a MEL-human hybrid cell line (Hu11) by homologous recombination, a similar stimulation of the SV40-neo gene is seen (Nandi et al., 1988). Such erythroid-specific transcription of the SV40-neo construct is not seen when the hybrid gene is integrated elsewhere in the genome outside the $\beta$-globin domain. By contrast, when the dominant control region is linked to the tk-neo gene, the promoter shows the high erythroid-specific expression, regardless of where it is integrated in the genome. This effect on the tk-neo gene is unrelated to the presence of the two $\beta$-globin gene enhancers, since their presence in large constructs without the flanking DCR does not result in a dramatic stimulation of the tk promoter (Wright et al., 1983). This implies that the DCR itself con- tains an inducible element and, indeed, when the $\beta$-globin gene is replaced with the Thy- 1 gene, both tk-neo and Thy-1 are induced. Since all the hypersensitive sites are already formed before the induction of the MEL cells and the start of globin transcription, we therefore suggest that the DCR contains elements of more than one function whose action is required or at least effected at different times during the differentiation of erythroid cells. The changes in chromatin structure would take place early (Figure 5) and clearly precede high levels of transcription, while a second inducible function (not detected in the chromatin structure of the DCR in these experiments) is linked to the actual transcription of the gene(s). The latter function would resemble the function of the $\beta$-globin gene enhancers (Behringer et al., 1987; Kollias et al., 1987a; Trudel et al., 1987; Antoniou et al., 1988), but be developmental stage-independent. Indeed, preliminary experiments suggest that one of the hypersensitive sites is associated with an erythroid-specific enhancer (Collis et al., unpublished data). In this respect, it is interesting to note that the $\beta$-globin gene as part of the minilocus is expressed in K562 cells that represent a different developmental stage.

\section{Expression in K562 Cells and the Regulation of Stage-Specific Expression}

$K 562$ cells do not express the endogenous $\beta$-globin gene or transfected $\beta$-globin genes without the upstream region (Kioussis et al., 1985; Antoniou et al., 1987; Rutherford and Nienhuis, 1987). This could simply mean that the proximity of the upstream DCR or the absence of some (unknown) repressive element in our minilocus construct is responsible for the low ( $10 \%$ of $\gamma$-globin levels), but substantial transcription of the $\beta$-globin gene. Interestingly, a similar phenomenon is observed in a number of human globin disorders, suggesting another possibility. Single point mutations have been detected in the $\gamma$-globin gene promoter (for review see Poncz et al., 1989), which appear to result in elevated levels of $\gamma$-globin gene transcription and a concomitant decrease in $\beta$-globin gene transcription. Conversely, deletion of the $\beta$-globin gene promoter (Anand et al., 1988; Atweh et al., 1987) correlates with an elevated expression of the $\gamma$-globin gene. These in vivo observations suggest that the expression of the $\gamma$ - and $\beta$-globin genes influence each other (for review, see Collins and Weissman, 1984; Poncz et al., 1989). We suggest that this phenomenon could be explained if the genes compete for some element in cis (perhaps the DCR or the $\beta$-globin gene enchancers) when they are present in the same domain. This competition would not be for any factor in trans, because many copies of the exogenous $\beta$-globin gene do not compete with the endogenous genes (Grosveld et al., 1987; this paper). Support for such a model in vivo has recently been provided by transient expression experiments with the chicken adult and embryonic globin genes in primitive and definitive chicken red cells (Choi and Engel, 1988). If such a mechanism is true for the human globin genes, the DCR of the $\beta$-globin domain would activate both the $\gamma$-and the $\beta$-globin genes independent of the stage of development. Each of the 
genes; i.e., the $\gamma$ or $\beta$-globin genes, would have a high efficiency of transcription at each of their optimal development stages, but have a significant, but lower (10\%-20\%), efficiency at the inappropriate stages of development when the single genes are present in the domain (as in the minilocus construct). When the other genes are present, this low level would be further decreased by competition with a more efficient gene. We are presently testing this model by using miniloci containing the $\gamma$ - and $\beta$-globin genes in isolation or together in cis.

\section{Experimental Procedures}

\section{Tissue Culture and Cell Transfections}

The $\beta$-globin minilocus cosmid (Grosveld et al., 1987) was linearized at the Pvul site in the vector. Transfection into the diploid MEL cell line C88 (Deisseroth and Hendrick, 1978) and K562 cells (Lozzio and Lozzio, 1975) was performed by electroporation as described (Smithies et al., 1985; Antoniou et al., 1988), into $\mathrm{L}$ cells by calcium phosphate precipitation (Wigler et al., 1979).

Directly after electroporation, the cells were split to give rise to three different populations. One percent of each of the C88 populations was plated out separately in small dishes from which individual clones were picked.

Selections for stable populations and clones were performed by adding $\mathrm{G} 418$ to the medium 2 days after transfection. The final $\mathrm{G} 418$ concentration for K562 and MEL cells was $800 \mu \mathrm{g} / \mathrm{ml}$; for $L$ cells 300 $\mu \mathrm{g} / \mathrm{ml}$. The obtained MEL populations and clones were induced as described (Antoniou et al., 1988). Copy number and possible deletions of parts of the transfected construct in all populations and clones were analyzed by Southern blotting (Southern, 1975).

\section{RNA Analysis}

RNA extraction of the transfected cell populations and clones was done in $3 \mathrm{M}$ lithium chloride, $6 \mathrm{M}$ urea including a $2 \mathrm{~min}$ sonication step (Auffray and Rougeon, 1980).

S1 nuclease protection analysis was carried out as described previously (Kollias et al., 1986).

Northern blotting was done as described by Krumlauf et al. (1987).

\section{DNAasel Sensitivity}

DNAasel sensitivity assays were carried out on isolated nuclei of confluent $\mathrm{C} 88, \mathrm{K562}$, and $\mathrm{L}$ cell populations as described previously (Grosveld et al., 1987)

\section{B-Globin Minilocus}

The construction of the $\beta$-globin minilocus was as previously described by Grosveld et al. (1987). The Thy-1 gene was flrst cloned as an EcoR mouse-human hybrid gene (Kollias et al., 1987b) in a polylinker between a Clal and Kpnl site. The gene was then exchanged for the $\beta$-globin Clal-Kpnl fragment in minilocus.

\section{Acknowledgments}

We are grateful to Mike Antoniou, Khai Siew, Jacky Hurst, and Gloria Charters for their expert technical assistance in tissue culture, to Fiona Watson for the Thy-1 probe, and to Cora O'Carroll for the preparation of the manuscript. G. B. was self-supported. This work is supported by the Medical Research Council (UK).

The costs of publication of this article were defrayed in part by the payment of page charges. This article must therefore be hereby marked "advertisement" in accordance with 18 U.S.C. Section 1734 solely to indicate this fact.

Received September 8, 1988; revised December 7, 1988.

\section{Reterences}

Anand, R., Brehm, C. D., Kazazian, H. H., and Vanin, E. F. (1988). Molecular characterization of a $\beta^{0}$-thalassaemia resulting from a $1.4 \mathrm{~kb}$ deletion. Blood 72, 636-641.
Antoniou, M., deBoer, E., and Grosveld, F. (1987). ß-globin gene promoter generates $5^{\prime}$ truncated transcripts in the embryonic foetal erythroid environment. Nucl. Acids Res. 15, 1886.

Antoniou, M., deBoer, E., Habets, G., and Grosveld, F. (1988). The human $\beta$-globin gene contains multiple regulatory regions: identification of one promoter and two downstream enhancers. EMBO J. 7, 377-384 Atweh, G., Zhu, X., Brickner, H., Dowling, C., Kazazian, H., and Forget, $B$. (1987). The $\beta$-globin gene on the Chinese $\delta \beta$-thalassaemia chromosome carries a promoter mutation. Blood 70, 1470-1474.

Auffray, C., and Rougeon, F. (1980). Purification of mouse immunoglobulin heavy-chain messenger RNAs from total myeloma tumour RNA. Eur. J. Biochem. 107, 303-314.

Baron, M. H., and Maniatis, T. (1986). Rapid reprogramming of globin gene expression in transient heterokaryons. Cell 46, 591-602.

Behringer, R. R., Hammer, R. E., Brinster, R. L., Palmiter, R. D., and Townes, T. M. (1987). Two 3 ' sequences direct erythroid specific ex pression of human $\beta$-globin genes in transgenic mice. Proc. Natl. Acad. Sci. USA 84, 7056-7060.

Busslinger, M., Hurst. J., and Flavell, R. A. (1983). DNA methylation and the regulation of globin gene expression. Cell 34, 197-206.

Choi, O.-R. B., and Engel, J. D. (1988). Developmental regulation of $\beta$-globin switching. Cell 55, 17-26.

Collins, F. S., and Weissman, S. M. (1984). The molecular genetics of human hemoglobin. Prog. Nucl. Acid Res. Mol. Biol. 31, 315-462.

deBoer, E., Antoniou, M., Mignotte, V., Wall, L., and Grosveld, F. (1988). The human $\beta$-globin gene promoter; nuclear protein factors and erythroid specific induction of transcription. EMBO J. 7, 4203-4212. Deisseroth, A., and Hendrick, D. (1978). Human a-globin gene expression following chromosomal dependent transfer into mouse Erythroleukemia cells. Cell $15,55-63$.

Dierks, P., van Ooyen, A., Mantei, N., and Weissman, C. (1981). DNA sequences preceding the rabbit $\beta$-globin gene are required for formation of $\beta$-globin RNA with the correct 5 ' terminus in mouse $L$ cells. Proc. Natl. Acad. Sci. USA 78, 1411-1414.

Forrester, W. C., Takegawa, S., Papayannopoulou, T., Stamatoyannopoulos, G., and Groudine, M. (1987). Evidence for a locus activating region: the formation of developmentally stable hypersensitive sites in globin expressing hybrids. Nucl. Acids Res. 15, 10159-10177.

Grosveld, F. G., Lund, T., Murray, E. J., Mellor, A. L., Dahl, H. H. M., and Flavell, R. A. (1982). The construction of cosmid libraries which can be used to transform eukaryotic cells. Nucl. Acids Res. 10 6715-6732.

Grosveld, F., Blom van Assendelft, G., Greaves, D. R., and Kollias, G. (1987). Position-independent, high-level expression of the human B.globin gene in transgenic mice. Cell 51, 975-985.

Kioussis, D., Vanin, E., deLange, T., Flavell, R. A., and Grosveld, F. (1983). B-globin gene inactivation by DNA translocation in $\gamma \beta$ thalassaemia. Nature 306, 662-666.

Kioussis, D., Wilson, F., Khazaie, K., and Grosveld, F. G. (1985) Differential expression of human globin genes introduced into K562 cells. EMBO J. 4, 927-931.

Kollias, G., Wrighton, N., Hurst, J., and Grosveld, F. (1986). Regulated expression of human $A_{\gamma-}, \beta$-, and hybrid $\gamma \beta$-globin genes in transgenic mice: manipulation of the developmental expression patterns. Cell 46. 89-94.

Kollias, G., Hurst, J., deBoer, E., and Grosveld, F. (1987a). A tissue and developmental specific enhancer is located downstream from the human $\beta$-globin gene. Nucl. Acids Res. 15, 5739-5747.

Kollias, G., Spanopoulou, E., Grosveld, F., Aitter, M., Beech, J., and Morris, R. (1987b). Differential regulation of a Thy-1 gene in transgenic mice. Proc. Natl. Acad. Sci. USA 84, 1492-1496.

Krumlauf, R., Holland, P., McVey, J., and Hogan, B. (1987). Developmental and spatial patterns of expression of the mouse homeobox gene Hox2.1. Development 99, 603-617.

Lozzio, C. B., and Lozzio, B. B. (1975). Human chronic myelogenous leukemia cell line with positive Philadelphia chromosome. Blood 45 , 321-324.

Magram, J., Chada, K., and Costantini, F. (1985). Developmental regu- 
lation of a cloned adult $\beta$-globin gene in transgenic mice. Nature $\mathbf{3 1 5}$, 338-340.

Murray, E., and Grosveld, F. (1987). Site specific demethylation in the promoter of the $\gamma$-globin gene does not alleviate methylation mediated suppression. EMBO J. 5, 2329-2335.

Nandi, A. K., Roginski, R. S., Gregg, R. G., Smithies, O., and Skoultchl, A. I. (1988). Regulated expression of genes inserted at the human chromosomal $\beta$-globin locus by homologous recombination. Proc. Natl. Acad. Sci. USA 85, 3845-3849.

Poncz, M., Henthorn, P., Stoeckert, C., and Surrey, S. (1989). Globin gene expression in hereditary persistence of fetal hemoglobin and $(\delta \beta)^{\circ}$ thalassemia. In Oxford Surveys on Eukaryotic Genes, N. Maclean, ed. (Oxford: Oxford University Press), in press.

Rutherford, T., and Nienhuis, A. W. (1987). Human globin gene promoter sequences are sufficient for specific expression of a hybrid gene transfected into tissue culture cells. Mol. Cell. Biol. 7, 398-402.

Smithies, O., Gregg, R. G., Boggs, S. S., Karalewski, M. A., and Kucherlapati, R. S. (1985). Insertion of DNA sequences into the human chromosomal $\beta$-globin locus by homologous recombination. Nature $317,230-234$.

Southern, E. (1975). Detection of specific sequences among DNA fragments separated by gel electrophoresis. J. Mol. Biol. 98, 503-517.

Taramelii, R., Kioussis, D., Vanin, E., Bartram, K., Groffen, J., Hurst, J., and Grosveld, F. (1986). $\gamma \delta \beta$-thalassaemias 1 and 2 are the result of a $100 \mathrm{~kb}$ deletion in the human $\beta$-globin cluster. Nucl. Acids Res. 14 7017-7029.

Trudel, M., Magram, J., Bruckner, L., and Costantini, F. (1987). Upstream ${ } \gamma$-globin and downsteam $\beta$-globin sequences required for stage-specific expression in transgenic mice. Mol. Cell. Biol. 7 4024-4029.

Tuan, D., Solomon, W., Qiliang, L. S., and Irving, M. L. (1985). The " $\beta$-like-globin" gene domain in human erythroid cells. Proc. Natl. Acad. Sci. USA 32, 6384-6388

van der Ploeg, L. H. T., Konings, A., Oort, M., Roos, D., Bernini, L., and Flavell, R. A. (1980). $\gamma \beta$-thalassaemia deletion of the $\gamma$ - and $\delta$-genes influences $\beta$-globin gene expression in man. Nature 283, 637-642.

Wall, L., deBoer, E., and Grosveld, F. (1988). The human $\beta$-globin gene $3^{\prime}$ enhancer contains multiple binding sites for an erythroid specific protein. Genes Dev. 2, 1089-1100.

Wigler, M., Sweet, R., Sim, G. K., Wold, B., Pellicer, A., Lacy, E., Maniatis, T., Silverstein, S., and Axel, R. (1979). Transformation of mammalian cells with genes from procaryotes and eucaryotes. Cell 16, 777-785. Wright, S., deBoer, E., Grosveld, F. G., and Flavell, R. A. (1983). Regulated expression of the human $\beta$-globin gene family in murine erythroleukaemia cells. Nature 305, 333-336.

Wrighton, N., and Grosveld, F. (1988). A novel in vitro transcription assay demonstrates the presence of globin-inducing trans-acting factors in uninduced Murine Erythroleukemia Cells. Mol. Cell. Biol. 8, 130-137. 